OPEN ACCESS

Edited by:

Mattijs Julsing,

Technical University of Dortmund,

Germany

Reviewed by:

Selin Kara,

Hamburg University of Technology,

Germany

Rajinder K. Gupta,

Guru Gobind Singh Indraprastha

University, India

*Correspondence:

Rajesh P. Singh

rpsbsfbs@iitr.ac.in

Specialty section:

This article was submitted to

Microbiotechnology, Ecotoxicology and Bioremediation,

a section of the journal

Frontiers in Microbiology

Received: 16 August 2016 Accepted: 09 December 2016 Published: 22 December 2016

Citation:

Agarwal $P$, Dubey S, Singh $M$ and Singh RP (2016) Aspergillus niger PA2 Tyrosinase Covalently Immobilized on a Novel Eco-Friendly Bio-Composite of Chitosan-Gelatin and Its Evaluation for L-DOPA Production.

Front. Microbiol. 7:2088. doi: 10.3389/fmicb.2016.02088

\section{Aspergillus niger PA2 Tyrosinase Covalently Immobilized on a Novel Eco-Friendly Bio-Composite of Chitosan-Gelatin and Its Evaluation for L-DOPA Production}

\author{
Pragati Agarwal, Swati Dubey, Mukta Singh and Rajesh P. Singh * \\ Department of Biotechnology, Indian Institute of Technology Roorkee, Roorkee, India
}

Tyrosinase (EC 1.14.18.1) a copper-containing monooxygenase, isolated from a fungal isolate Aspergillus niger PA2 was subjected for immobilization onto a composite consisting of chitosan and gelatin biopolymers. The homogeneity of the chitosan-gelatin biocomposite film was characterized by X-ray diffraction analyses. To evaluate immobilization efficiency, chitosan-gelatin-Tyr bio-composite films were analyzed by field emission scanning electron microscopy, atomic force microscopy and UV-spectroscopy. The rough morphology of the film led to a high loading of enzyme and it could retain its bioactivity for a longer period. The enzyme adsorbed onto the film exhibited $72 \%$ of its activity after 10 days and exhibited good repeatability for up to nine times, after intermittent storage. Moreover, the immobilized enzyme exhibited broader $\mathrm{pH}$ and temperature profile as compared to free counterpart. Immobilized enzyme was further evaluated for the synthesis of L-DOPA (2,4-dihydroxy phenylalanine) which is a precursor of dopamine and a potent drug for the treatment of Parkinson's disease and for myocardium neurogenic injury.

Keywords: Immobilization, tyrosinase, chitosan, gelatin, L-DOPA

\section{INTRODUCTION}

Enzymes have enormous potential to be used as catalysts in a wide range of biotechnological and industrial processes. They offer a distinct advantage due to their specificity, high catalytic efficiency and biodegradability (Bullock, 1995; Munjal and Sawhney, 2002). A common drawback of enzymatic procedures is the consumption of expensive enzyme molecules during the process (Fiorentino et al., 2010). Thus, the industrial exploitation of enzymes is limited due to their nonreusability and instability (Wang et al., 2009). Enzyme immobilization has been found to be a promising way to overcome these limitations and to enhance the catalytic performance of enzymes (Ensuncho et al., 2005; Arica and Bayramoglu, 2006; Bayramoglu et al., 2012). Immobilization of enzyme has several advantages, such as improved stability by protecting the protein from deactivation, high reproducibility, improved thermal and storage stability, significant reduction in the production cost, easy recovery of the enzyme and continuous and repeated use (Cirpan et al., 2003; Yildiz et al., 2013). 
Polymer blending is one of the most productive approaches for providing novel and desirable polymeric materials to immobilize enzymes (Tembe et al., 2006). The composite thus prepared, combine the physicochemical attributes of both components and overcome their shortcomings (Gupte and D'Souza, 1999; Jha and D'Souza, 2005). Also this simplyprepared protein-polysaccharide bio-composite film facilitates the enzymes to retain their activity (Forzani et al., 1999, 2000). Biocompatible polymers have their unique advantages for enzyme immobilization, as they aid in retaining the activity of enzyme well by providing desirable micro-environment ( $\mathrm{Li}$ et al., 2006). Chitosan (2-acetamido-2-deoxy-d-glucose) is an $\mathrm{N}$ deacetylated derivative with chemically modified acetyl group of chitin. Chitosan is widely considered to be a biocompatible, nontoxic and chemically distinctive polysaccharide which occurs as a natural biopolymer in the exoskeleton of crustaceans and in fungal cell wall (Liu et al., 2005). Due to its unique chemical properties, such as excellent membrane-forming ability, high permeability toward water, good adhesion, biocompatibility, non-toxicity, biodegradability, high mechanical strength and susceptibility to chemical modifications due to the presence of reactive amino and hydroxyl functional groups (Cruz et al., 2000), chitosan serves as a matrix for the assembly of biomolecules including enzymes, DNA, and antibodies (Ye et al., 2005; Tan et al., 2009; Xu et al., 2010). Gelatin is also a naturally occurring biopolymer having good adhesion qualities and non-toxicity. It is commonly used as a gelling agent in food, such as marsh mallows, desserts, ice-creams and pharmaceuticals. Also it is commonly used as a biological substrate to culture adherent cells. The composite film consisting of chitosan and gelatin mixed and gelled together, can overcome the brittleness of pure chitosan matrix and its shrinkage. Another advantage of this blend is that both the polymers are biocompatible, transparent, safe, abundant and inexpensive, thereby providing substantial microenvironment for enzyme to be immobilized.

Tyrosinase is a copper containing multifunctional metalloenzyme that catalyzes the hydroxylation of monophenols to $o$-diphenols (monophenolase or cresolase activity) and the oxidation of the latter to $o$-quinones (diphenolase or catecholase activity), using oxygen (Labus et al., 2011). The two activities can be used as the basis for widespread biotechnological and industrial applications, such as biosensors to determine the phenolic content in waste water (Atlow et al., 1984), for bioremediation of phenolic effluents and for biotransformation of L-tyrosine to L-DOPA, the preferred drug for Parkinson's disease.

Previously chitosan-gelatin composite formation has been studied by Chen et al. (2003), Basavaraju et al. (2006), and Mi (2005) and its application for food products had been explored by Arvanitoyannis et al. (1998) and Lo’pez-Caballero et al. (2005), but this bio-composite had never been investigated to be used as a matrix for tyrosinase immobilization. However, several workers have endeavored to immobilize tyrosinase onto alginate, polyacrylamide and gelatin gels (Munjal and Sawhney, 2002), $\mathrm{ZnO}$ nanoparticles (Li et al., 2006), cellulose support (Labus et al., 2011) and polystyrene microplate (Saini et al., 2014). Moreover, this is the first report of immobilization of tyrosinase from $A$. niger on any support matrix.

In the present study, tyrosinase from $A$. niger PA2 had been immobilized onto a bio-composite film consisting of chitosan and gelatin polymers (Figure 1). The prepared films were thoroughly characterized using XRD, FESEM, AFM, and UVspectroscopy and the efficiency of immobilized tyrosinase was evaluated in terms of stability, reusability and for the production of L-DOPA.

\section{MATERIALS AND METHODS}

\section{Materials}

Chitosan and gelatin were procured from Sigma-Aldrich (India). All other chemicals bought were of analytical grade. Solutions and reagents were prepared using Milli-Q water.

\section{Enzyme Preparation}

For the production of tyrosinase, A. niger PA2 isolated from waste water effluent (Agarwal et al., 2016) was grown in Vogel's medium (Vogel, 1956) at $30^{\circ} \mathrm{C}(150 \mathrm{rpm})$ for $5-6$ days. The supernatant from the culture was filtered using cheese cloth and the filtrate thus obtained was centrifuged at $6000 \mathrm{rpm}$ for 15 min and the supernatant was used as the crude preparation. The crude preparation was further subjected to ammonium sulfate fractionation (25-75\%). Briefly, for each saturation ammonium sulfate was added to the above preparation and the mixture was stirred for $1 \mathrm{~h}$ at $4^{\circ} \mathrm{C}$ and then centrifuged (10,000 rpm, $45 \mathrm{~min}$ ). Supernatant obtained was further added with ammonium sulfate so as to achieve further saturation. The precipitate obtained was collected and redissolved in $20 \mathrm{ml}$ of fresh extraction buffer (50 $\mathrm{mM}$ phosphate buffer, $\mathrm{pH}$ 6.5) and dialyzed against the same buffer for $10 \mathrm{~h}$ at $4^{\circ} \mathrm{C}$. The concentrated enzyme thus obtained was stored at $4^{\circ} \mathrm{C}$ (Munjal and Sawhney, 2002; Saini et al., 2014).

\section{Composite Film Preparation}

Acidic solutions of chitosan $(2 \%, 2 \mathrm{ml})$ and gelatin $(2 \%, 2 \mathrm{ml})$ were prepared separately by dissolving in acetic acid $(1 \%, \mathrm{v} / \mathrm{v})$ and then were mixed together in 1:1 proportion. This mixture was stirred for $4 \mathrm{~h}$ at room temperature and the homogeneous blend was then spread uniformly on a glass plate $\left(9 \mathrm{~cm}^{2}\right)$ and kept overnight in a dust-free hood for drying. The composite film of biopolymers, thus obtained was stored at $4{ }^{\circ} \mathrm{C}$ under dry conditions and was rinsed with phosphate buffer (0.1M, $\mathrm{pH} 8.0)$ before use (Tembe et al., 2006).

\section{Characterization of Film through X-Ray Diffraction Analysis}

The powder X-ray patterns of the chitosan, gelatin and composite films were obtained using a Bruker D8 ADVANCE X-ray diffractometer, with $\mathrm{Ni}$-filter and $\mathrm{Cu}-\mathrm{K} \alpha$ radiation $(\lambda=1.544 \AA$ ) at a voltage of $40 \mathrm{kV}$ and at $30 \mathrm{~mA}$. Samples were scanned for relative intensity over the range of diffraction angle $2 \theta=5-70^{\circ}$, with a scan speed of $1^{\circ} / \mathrm{min}$ at room temperature (Xu et al., 2006). Prior to testing, the samples were dried and stored in a hot air oven. 


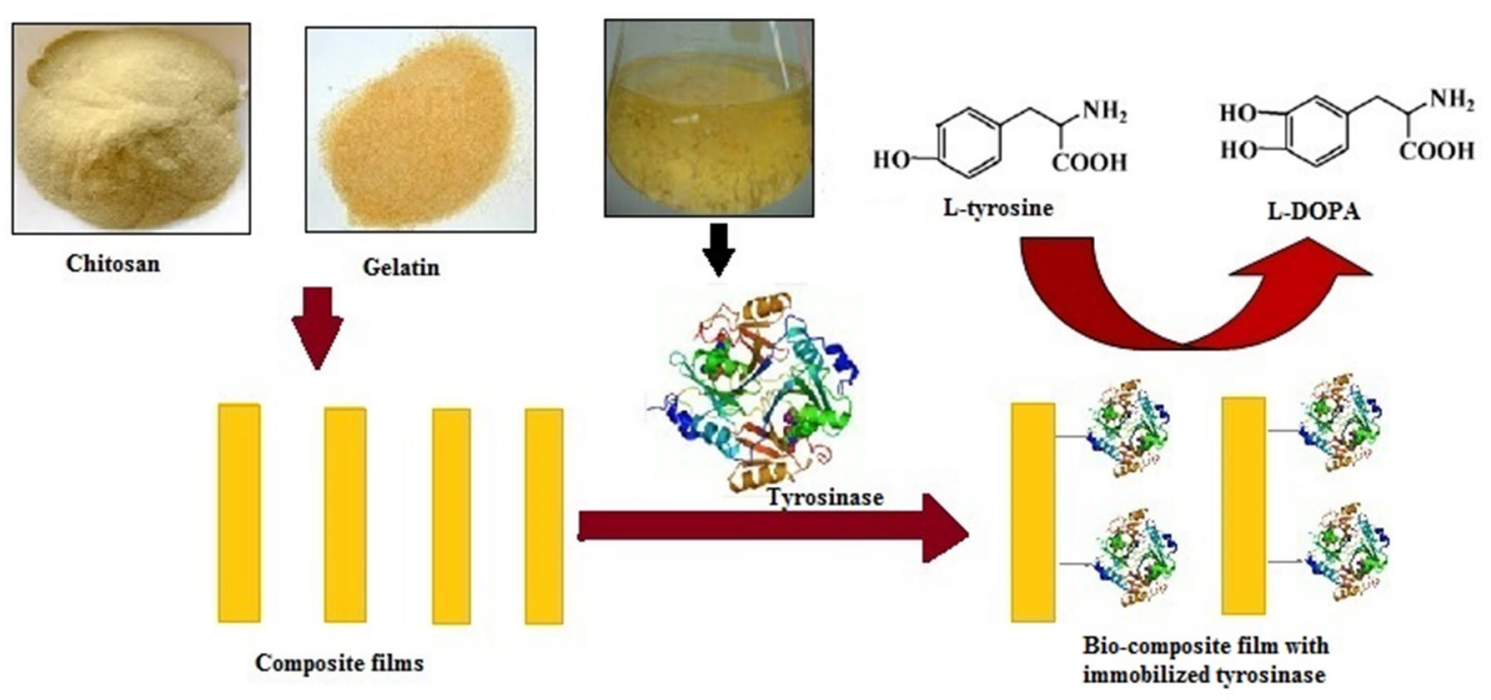

FIGURE 1 | Schematic representation of immobilization of Aspergillus niger PA2 tyrosinase onto chitosan-gelatin composite film and L-DOPA production.

\section{Immobilization of Enzyme}

After washing with $0.1 \mathrm{M}$ phosphate-buffered saline (pH 7.5), the carrier film was suspended in a tyrosinase solution at $4^{\circ} \mathrm{C}$ for overnight incubation. The unbound enzyme was removed by washing with $0.1 \mathrm{M}$ sodium phosphate buffer ( $\mathrm{pH}$ 8.0). Further, these films were rinsed with a $0.1 \mathrm{M}$ phosphate-buffered saline $(\mathrm{pH}$ 7.5) to remove any unbound protein. The immobilized preparation was stored in the above phosphate buffer at $4^{\circ} \mathrm{C}$ till further use (Labus et al., 2011).

\section{Characterization of Immobilization Field Emission Scanning Electron Microscopy}

The changes in surface structure and morphology of films consisting of chitosan, gelatin, chitosan-gelatin composite and composite film after immobilization of tyrosinase were observed using a Carl Zeiss Ultra Plus FESEM system (Germany) at an accelerating voltage of $10-20 \mathrm{kV}$.

\section{Atomic Force Microscopy}

To investigate the homogeneity of the films, the surface morphology of composite films before and after the immobilization of tyrosinase was observed using atomic force microscopy using NT-MDT (Moscow, Russia) multiple function unit. Different areas of control film and the film with immobilized enzyme were visualized under the same conditions. The average root mean square roughness of the film surface was collected using the topographical data obtained from AFM micrographs (Saini et al., 2014).

\section{UV Spectral Analysis}

Spectral changes with the free and immobilized enzyme were recorded in a range from 250 to $750 \mathrm{~nm}$. For the assessment of monophenolase reaction of immobilized tyrosinase, films $\left(9 \mathrm{~cm}^{2}\right)$ were immersed in $3.0 \mathrm{ml}$ of $0.5 \mathrm{M}$ phosphate buffer solution ( $\mathrm{pH}$
6.5) containing $0.001 \mathrm{M} \mathrm{L}$-tyrosine and 2\% L-ascorbic acid for 10 min. All absorption spectra were recorded with CARY 100 Bio UV-Vis spectrophotometer (Agilent technologies, USA) at room temperature.

\section{Estimation of Tyrosinase Activity}

The tyrosinase activity was determined by using L-tyrosine as substrate (Chen et al., 2001; Liu et al., 2004; Arica et al., 2007; Raval et al., 2012). For this the membrane with the immobilized enzyme $\left(9 \mathrm{~cm}^{2}\right)$ was kept in phosphate buffer $(0.5 \mathrm{M}, \mathrm{pH} 6.5)$ containing $1 \mathrm{mM}$ L-tyrosine with $2 \% \mathrm{~L}$-ascorbic acid. Tyrosinase activity was estimated at $280 \mathrm{~nm}$ for 10 min using CARY 100 Bio UV-Vis spectrophotometer (Agilent technologies, USA). One unit of tyrosinase activity was equal to a $\Delta \mathrm{A}_{280}$ of $0.001 / \mathrm{min}$ at $30^{\circ} \mathrm{C}$ in the reaction mixture containing L-tyrosine and L-ascorbic acid. All experiments were carried out in triplicate. The $\mathrm{Y}$ error bars in the figures indicate the standard error of the mean.

\section{Properties of Free and Immobilized Enzyme} Thermostability and pH Stability

A series of experiments were performed in order to characterize the immobilized enzyme response. Enzyme solution was freshly prepared every time. Thermal stability of both free and immobilized tyrosinase was determined by incubating the preparations at different temperatures i.e., $25-55^{\circ} \mathrm{C}$ for $60 \mathrm{~min}$ at constant $\mathrm{pH}$. After incubation the preparation was left at room temperature for $60 \mathrm{~min}$ to equilibrate and was then assayed for enzyme activity as described above. All experiments were performed in triplicates and the relative enzyme activity was calculated by assigning the maximum activity as $100 \%$.

The effect of $\mathrm{pH}$ on the activity of free and immobilized tyrosinase was studied in the $\mathrm{pH}$ range $4.0-8.0$. For this two 
different buffer systems acetate buffer (for $\mathrm{pH} 4.0-5.0$ ) and phosphate buffer (for $\mathrm{pH}$ 6.0-8.0) were employed. The optimum $\mathrm{pH}$ was determined by incubating the preparation at a given $\mathrm{pH}$ for $60 \mathrm{~min}$ at constant temperature. Then the $\mathrm{pH}$ of the preparation was adjusted to 7.0 and it was left for $60 \mathrm{~min}$ to equilibrate and then assayed for enzyme activity (Labus et al., 2011; Bayramoglu et al., 2013).

\section{Loading Efficiency, Storage Stability, and Operational Stability}

For leaching studies, the ratio of the activities of tyrosinase adsorbed onto the membrane and the activity of enzyme before the immobilization was evaluated. To analyze the bound enzyme, membrane with immobilized enzyme was kept in assay buffer containing $1 \mathrm{mM}$ L-tyrosine and 2\% L-ascorbic acid for $10 \mathrm{~min}$ and the buffer was then decanted to a cuvette and the activity in the decanted solution was determined. The amount of enzyme that had leached out was calculated with the difference of initial enzyme activity and activity of adsorbed enzyme. Together they signify the percent of enzyme adsorbed onto the matrix and the enzyme that had been leached out (Munjal and Sawhney, 2002; Tembe et al., 2006).

Loading efficiency $(\%)=\frac{\text { Activity of immobilized enzyme }}{\begin{array}{c}\text { Activity of free enzyme before } \\ \text { immobilization }\end{array}} \times 100$

Enzymes can easily be denatured and lose their catalytic activity. Therefore, operational and storage stabilities are essential parameters for an immobilized enzyme (Yildiz et al., 2013). The storage stabilities of the free and immobilized enzymes were investigated by storing in $0.1 \mathrm{M}$ phosphate buffer $(\mathrm{pH} 7.0)$ at $4^{\circ} \mathrm{C}$ for a period of 20 days. Change in activity was measured at every 5 th day for both the preparations.

The operational reusability of immobilized tyrosinase was examined by measuring the enzymatic activity of the same preparation successively for nine times using L-tyrosine as substrate. After each measurement, the membrane with immobilized enzyme was washed with phosphate buffer $(0.1 \mathrm{M}$, $\mathrm{pH}$ 7.0) to remove any residual substrate and incubated in the same buffer for $1 \mathrm{~h}$ for equilibration. After that, the preparation was transferred into fresh reaction medium and enzyme activity was determined (Bayramoglu et al., 2013).

\section{L-DOPA Production by Immobilized Enzyme}

Partially purified and immobilized enzymes were evaluated for L-DOPA production by keeping the membrane in phosphate buffer $(0.5 \mathrm{M}, \mathrm{pH} 6.5)$ containing $3 \mathrm{mg} \mathrm{ml}^{-1}$ L-tyrosine and $2 \%$ ascorbic acid. The amount of L-DOPA was determined according to the Arnow's method (Arnow, 1937). Briefly, $1 \mathrm{ml}$ of above assay buffer was added with $1 \mathrm{ml}$ of $0.5 \mathrm{M} \mathrm{HCl}$ and $1 \mathrm{ml}$ of nitrate/molybdate reagent (giving yellow color) and then with $1 \mathrm{ml}$ of $1 \mathrm{M} \mathrm{NaOH}$ (giving red color). Water was added to make a final volume to $5 \mathrm{ml}$. L-DOPA was estimated at $590 \mathrm{~nm}$.

\section{RESULTS}

\section{Film Characterization through X-Ray Diffraction Analysis}

$\mathrm{X}$-ray diffraction pattern of chitosan, gelatin and composite films were obtained and compared, which revealed marked differences in their structures (Figure 2). The diffraction pattern of chitosan exhibited distinct crystalline peaks at around $2 \theta$ values 10 and $20^{\circ}$, while XRD pattern of gelatin powder showed greater amorphous morphology with a characteristic broad hump in the range of $15-30^{\circ} 2 \theta$. It was also noticed that the crystalline peaks of chitosan disappeared as the composite was formed between chitosan and gelatin, instead a new very small peak was observed in the blend at $2 \theta$ around $29^{\circ}$. Also the broadened hump which was present in gelatin became lower in the composite film (15$25^{\circ}$ ), demonstrating an interaction between the two components.

\section{Characterization of Immobilization}

\section{Field Emission Scanning Electron Microscopy}

The physical morphologies of the chitosan, gelatin, chitosangelatin composite and tyrosinase immobilized hybrid films were observed by FESEM. The cross-sectional FESEM image of chitosan film exhibited many tiny pores, whereas gelatin film displayed regularly ordered particulate morphology (Figure 3). Chitosan-gelatin composite membrane is a cross-linked threedimensional (3D) polymer network with a few smaller sphere particles filled in the mess space. When tyrosinase was adsorbed onto the film matrix, the network like structure disappeared and instead a regularly distributed aggregated smear was observed.

\section{Atomic Force Microscopy}

Immobilization of tyrosinase onto the composite film surface was also characterized by AFM micrographs. A typical AFM image of the surface of the chitosan-gelatin biocomposite membrane displayed a three-dimensional rough surface (Figure 4A). Tyrosinase immobilized matrix surface showed noticeable

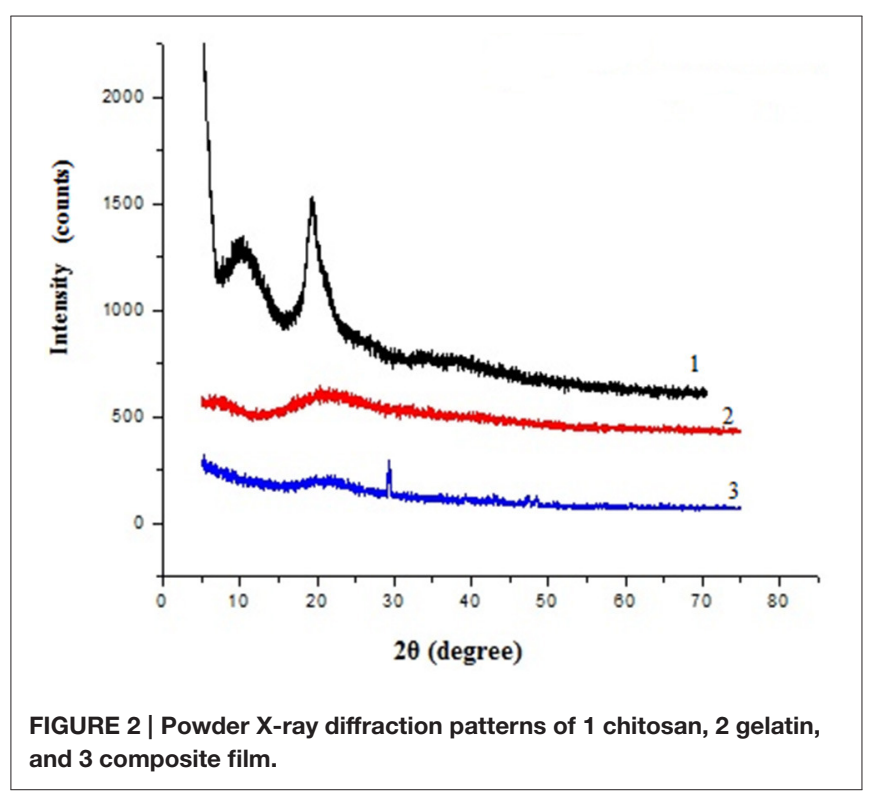


A

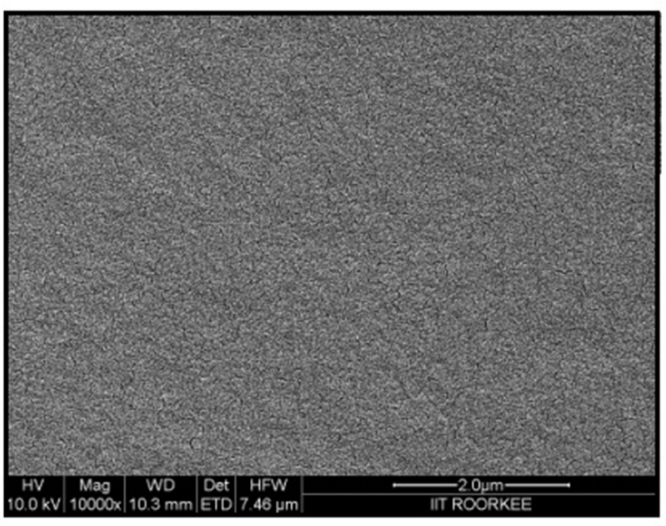

C

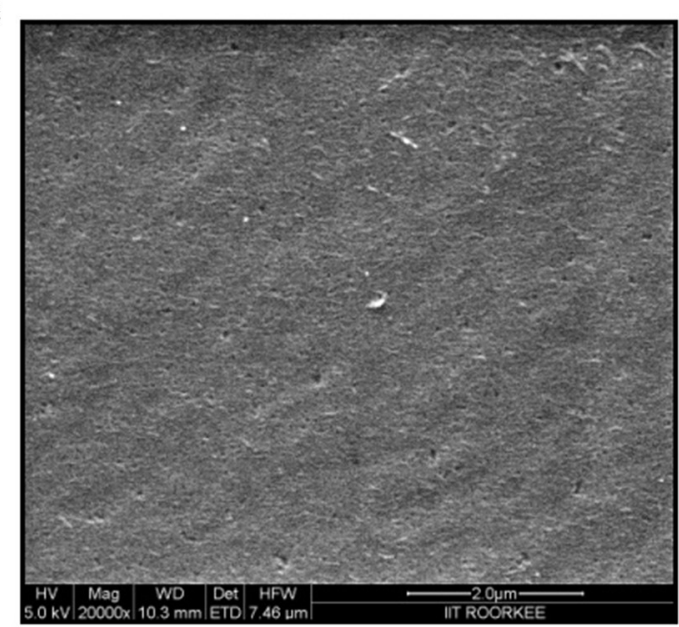

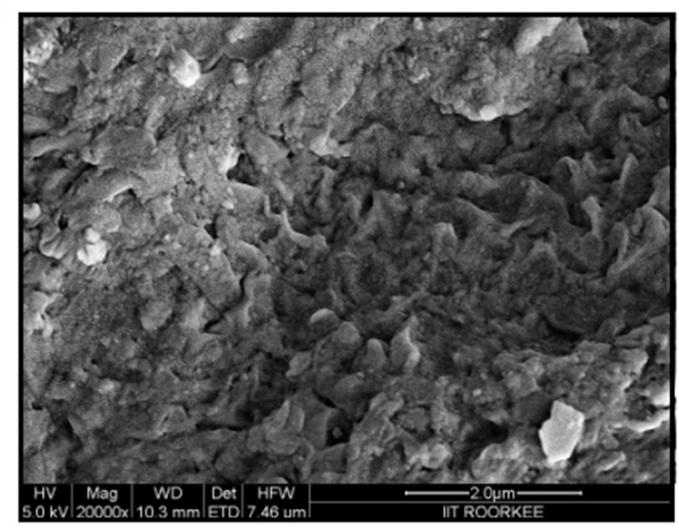

D

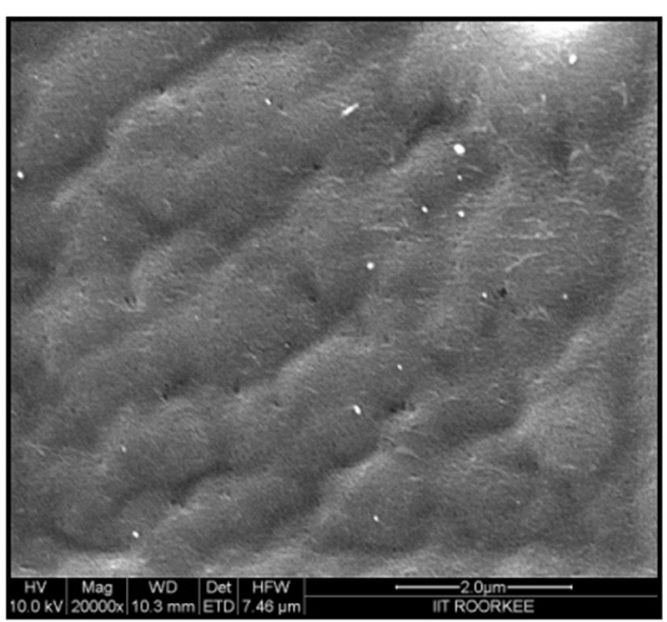

FIGURE 3 | FESEM images of chitosan film (A), gelatin film (B), chitosan-gelatin composite film (C), and composite film with immobilized tyrosinase (D).

differences as compared to the control matrix (Figure 4B). The rough surface that was present on the blank film was more prominent after the adsorption of the enzyme onto its surface. For the blank film, the average root mean square roughness was observed to be $1.95 \mathrm{~nm}$ and after adsorption of the tyrosinase onto its surface, the value increased to $3.48 \mathrm{~nm}$.

\section{UV Spectral Analysis}

Spectral changes during the course of reaction were recorded by performing wavelength scan $(250-750 \mathrm{~nm})$ for detection of L-DOPA. Figure 5 shows absorption spectra of the blank film, immobilized tyrosinase and free tyrosinase in the presence of L-tyrosine after $10 \mathrm{~min}$ of incubation. As evident from the spectra no change in absorbance was observed for the blank film, while free tyrosinase and film with immobilized tyrosinase had depicted absorption maxima at $280 \mathrm{~nm}$.

\section{Properties of Free and Immobilized Enzyme \\ Thermostability and pH Stability}

Soluble enzyme was most stable at $25^{\circ} \mathrm{C}$ and the stability decreased thereafter after increasing the temperature
(Figure 6A). However, enzyme had 58\% of the activity remaining following incubation at $55^{\circ} \mathrm{C}$. Whereas, enzyme following immobilization appears to have increased thermostability, as only $14 \%$ loss of activity was observed at $55^{\circ} \mathrm{C}$ following immobilization. Relative enzyme activity was calculated by assigning the maximum activity value as $100 \%$.

Free enzyme was observed to be most active at $\mathrm{pH} 5.0$ with a quick drop in its activity at acidic and basic $\mathrm{pH}$, while the $\mathrm{pH}$ profile of the immobilized tyrosinase displayed comparatively better activity in a broader $\mathrm{pH}$ range (5.0-8.0) with maximum activity at pH 6.0 (Figure 6B).

\section{Loading Efficiency, Storage Stability, and Operational Stability}

As observed about $72 \%$ retention of activity was observed following immobilization as compared to the free enzyme preparation, thus portraying the immobilization to be reasonably effective.

The activity of the immobilized tyrosinase decreased more slowly compared to the free tyrosinase under the similar storage conditions. Free tyrosinase retained only $71 \%$ of its original activity after 5 days of incubation while immobilized enzyme was 

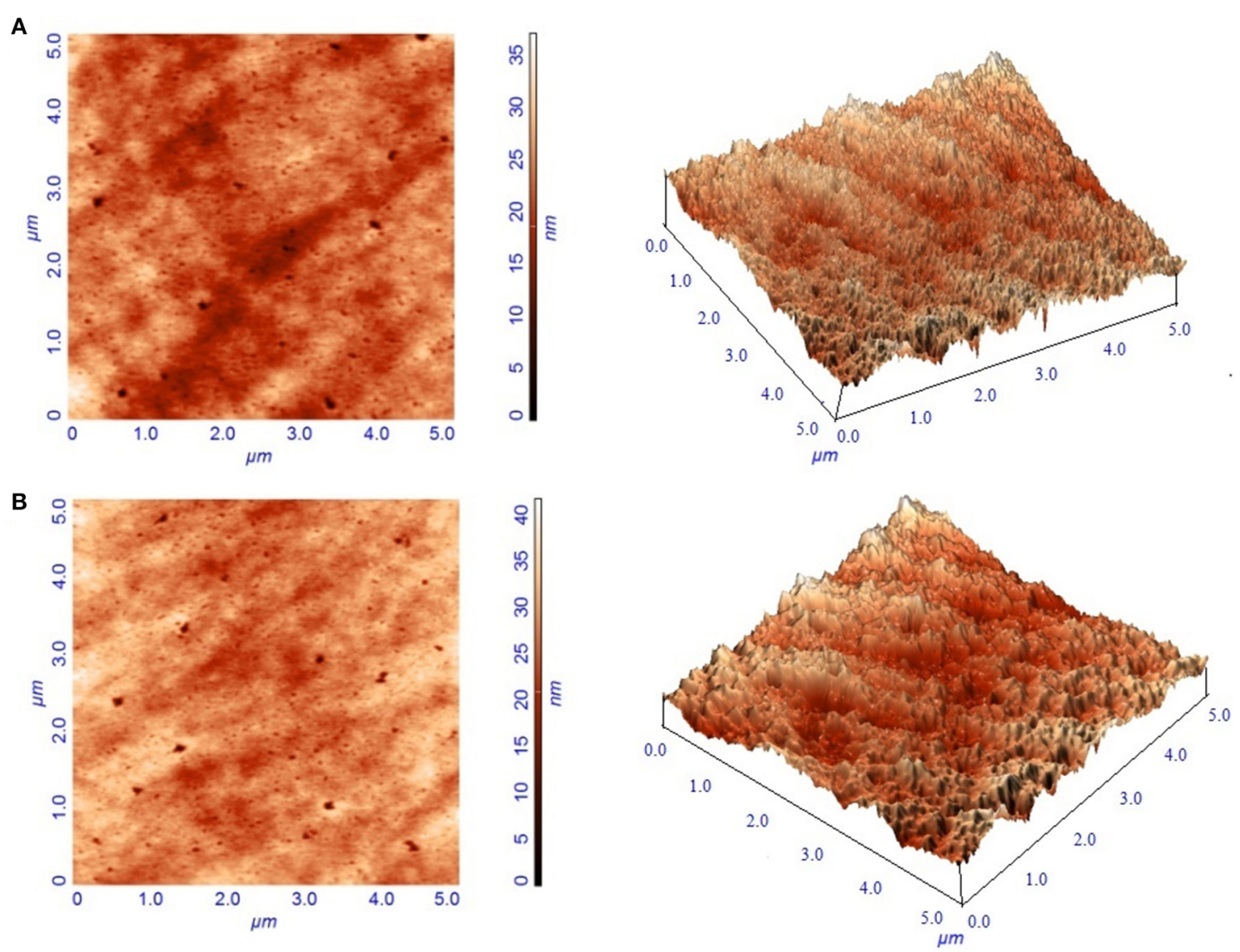

FIGURE 4 | Atomic force micrographs of blank composite film (A) and film with immobilized tyrosinase (B).

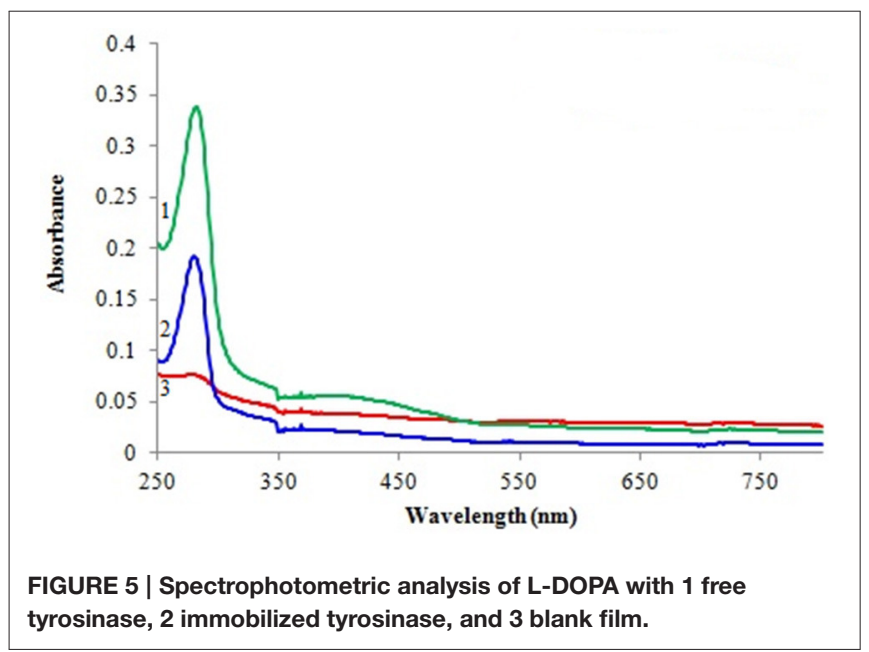

observed to have $84 \%$ activity. Free enzyme lost almost $40 \%$ of its initial activity within 10 days, whereas the immobilized enzyme maintained more than $72 \%$ of its original activity after 10 days, when stored at $4^{\circ} \mathrm{C}$ (Figure 7A).

Operational stability of enzyme-composite preparation was evaluated following 9 repetitive cycles (Figure 7B). The immobilized tyrosinase maintained $97 \%$ of its activity and produced $1.44 \mathrm{mg} \mathrm{ml}^{-1} \mathrm{~L}$-DOPA until 4 th cycle and retained $84 \%$ of its activity and produced $1.23 \mathrm{mg} \mathrm{ml}^{-1} \mathrm{~L}$-DOPA even following six successive cycles.

\section{L-DOPA Production}

Addition of nitrite-molybdate reagent to the buffer with immobilized enzyme led into the formation of yellow color. Further addition of sodium hydroxide resulted into the development of a red color, similar to the one developed with partially purified enzyme. L-DOPA levels obtained were $1.9 \mathrm{mg} \mathrm{ml}^{-1}$ and $1.7 \mathrm{mg} \mathrm{ml}^{-1}$ with partially purified and immobilized enzyme, respectively (Table 1 ). The L-DOPA production declined to $55 \%$ after $48 \mathrm{~h}$ and then to $27 \%$ following $72 \mathrm{~h}$ of storage with partially purified enzyme, while immobilized enzyme still had resulted into $88 \%$ and 56\% L-DOPA production after $48 \mathrm{~h}$ and $72 \mathrm{~h}$ of storage, respectively.

\section{DISCUSSION}

Tyrosinase from A. niger PA2 has been immobilized onto a biocomposite film consisting of chitosan and gelatin polymers. The homogeneity of the film was characterized by X-ray diffraction 

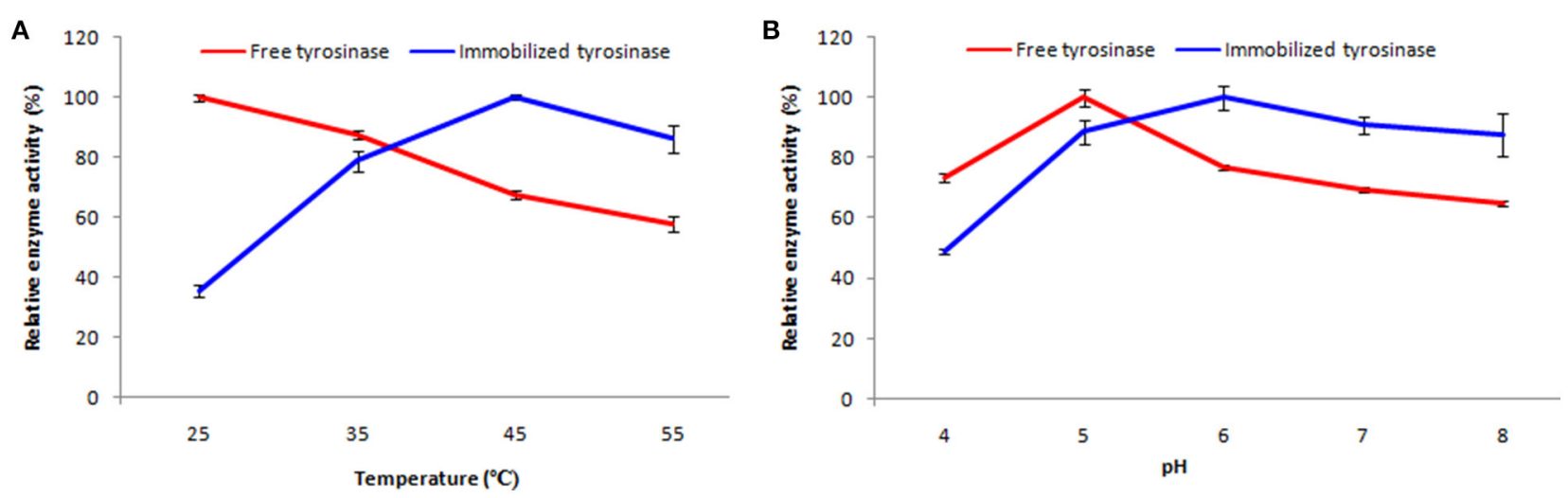

FIGURE 6 | Effect of temperature (A) and pH (B) on percent activity of free and immobilized tyrosinase. The experiments were performed in triplicate and standard deviations are shown as error bars.
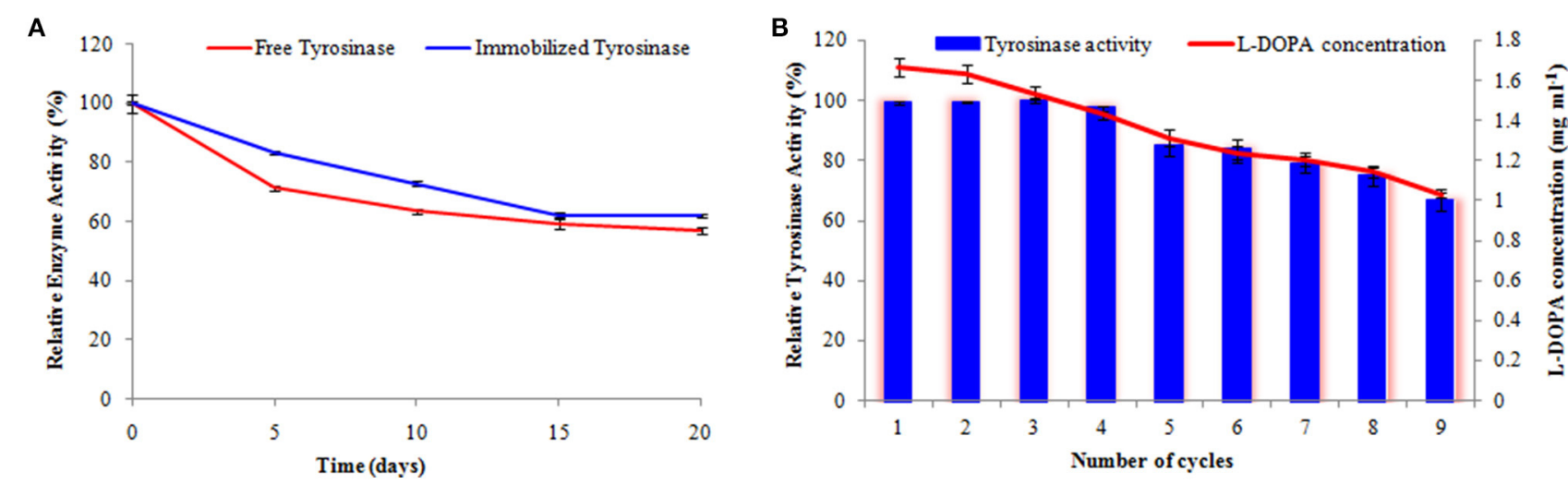

FIGURE 7 | Activity of free and immobilized tyrosinase during the course of storage (A) and retention in enzyme activity and L-DOPA production following repetitive cycles (B). The experiments were performed in triplicate and standard deviations are shown as error bars.

TABLE 1 | L-DOPA production with free and immobilized tyrosinase.

\begin{tabular}{lcc}
\hline Time (h) & \multicolumn{2}{c}{ L-DOPA production $\left(\mathbf{m g ~ m l}^{-\mathbf{1}}\right)$} \\
\cline { 2 - 3 } & Free Enzyme* & Immobilized Enzyme* \\
\hline 24 & $1.901 \pm 0.012$ & $1.701 \pm 0.050$ \\
48 & $1.054 \pm 0.021$ & $1.491 \pm 0.021$ \\
72 & $0.504 \pm 0.050$ & $0.954 \pm 0.026$ \\
\hline
\end{tabular}

*The experiments were performed in triplicate and standard deviations are shown as error bars.

analyses (Figure 2). The distinct crystalline peaks observed in the diffraction pattern of chitosan were due to the abundance of $-\mathrm{OH}$ and $-\mathrm{NH}_{2}$ groups in the chitosan structure, which could form strong inter and intra molecular hydrogen bonds and thus the chitosan molecules form crystalline regions and gain certain regularity easily (Ramya et al., 2012). While a broad hump observed in XRD pattern of gelatin powder was due to its amorphous morphology. It was also observed that the crystalline peaks of chitosan disappeared as the composite was formed between chitosan and gelatin, which is due to the elimination of hydrogen bonding between amino groups and hydroxyl groups in chitosan (Smitha et al., 2005). Also the broadened hump which was present in gelatin became lower in the composite film, demonstrating an interaction between the two components. To evaluate immobilization efficiency, chitosangelatin-Tyr bio-composite films were analyzed by FESEM, AFM and UV-spectroscopy. As observed through FESEM, chitosangelatin composite membrane is a cross-linked three-dimensional network with a few smaller sphere particles filled in the mess space (Figure 3). This network like structure could contribute a significant role toward the high enzyme stability within the polymer matrix providing a large surface area for efficient immobilization of enzyme (Liu et al., 2005). When tyrosinase was immobilized onto the film matrix, the network like structure disappeared and instead a regularly distributed aggregated smear was observed. A typical AFM image of the surface of the chitosan-gelatin bio-composite membrane displayed a three-dimensional rough surface (Figure 4), which provided a significantly larger surface area, improving its loading efficiency for the immobilization of biomolecules and other substances and also effectively preventing the leaking of biomolecule from the preparation. The roughness of the film surface is an important aspect that may provide information about the surface 
modifications after immobilization. It was apparent that the surface of the blank film is less rough than that of immobilized preparation. Increase in the roughness value after adsorption of the enzyme suggests the deposition of enzyme molecules onto the matrix surface (Saini et al., 2014). UV-spectral analysis also depicted the formation of L-DOPA, when the film with immobilized enzyme was immersed in buffer containing Ltyrosine (Figure 5). Soluble enzyme was most stable at $25^{\circ} \mathrm{C}$ and the stability decreased thereafter after increasing the temperature (Figure 6A), whereas, enzyme following immobilization appears to have increased thermostability at higher temperature i.e., upto $55^{\circ} \mathrm{C}$. Munjal and Sawhney (2002) obtained similar results with gelatin gel. They observed temperature optima for free tyrosinase from mushroom at $20^{\circ} \mathrm{C}$, while the tyrosinase immobilized onto gelatin gel demonstrated the optima at $40^{\circ} \mathrm{C}$. Labus et al. (2011) observed temperature maxima for Agaricus bisporus tyrosinase around $15-25^{\circ} \mathrm{C}$, while enzyme immobilized onto cellulose based carrier had shown maxima around $30-40^{\circ} \mathrm{C}$. Bayramoglu et al. (2013) obtained the optimum reaction temperature for the immobilized tyrosinase onto biosilica at $45^{\circ} \mathrm{C}$, which was $10^{\circ} \mathrm{C}$ higher than its free counterpart. The comparatively higher thermostability of the immobilized enzyme as compared to the soluble enzyme may possibly be due to its conformational rigidity due to the enzymatic interactions with the matrices (Labus et al., 2011; Bayramoglu et al., 2013) and thus preventing the unfolding (Mateo et al., 2007; Zhang et al., 2011). pH is one of the vital factors influencing the amino acid nature in the protein structure. Free enzyme was observed to be most active at $\mathrm{pH} 5.0$ with a quick drop in its activity at acidic and basic $\mathrm{pH}$. While the $\mathrm{pH}$ profile of the immobilized tyrosinase displayed comparatively better activity in a broader $\mathrm{pH}$ range (Figure 6B). Labus et al. (2011) observed $\mathrm{pH}$ optima with tyrosinase immobilized onto cellulose based carrier around $\mathrm{pH}$ 7.0-9.0, while free tyrosinase was most active around $\mathrm{pH}$ 6.0-7.0. These results implied that the immobilization led to retention of the enzyme activity at extreme $\mathrm{pH}$ due to adsorption of tyrosinase within the support matrix (Monsan, 1978; Bayramoglu and Arica, 2010; Li et al., 2012), thus making this biocatalyst more suitable for industrial exploitation (Bayramoglu et al., 2013). For leaching studies, the ratio of the activities of tyrosinase adsorbed onto the membrane and the activity of free enzyme i.e., before immobilization was calculated. About $72 \%$ of activity was retained following immobilization as compared to the free counterpart. It was also expected beforehand that immobilized/free tyrosinase activity ratio should be lower than 1.0 (Labus et al., 2011). Thus, this matrix proves to be a biocompatible composite that provides a natural environment to the enzyme, minimizing it's leaching, retaining the activity and therefore making the immobilization highly productive. Generally there is a gradual decrease in enzyme activity upon storage and immobilization significantly slows down this phenomenon (Figure 7A). The activity of the immobilized tyrosinase decreased more slowly compared to the free tyrosinase under the similar storage conditions. Immobilized enzyme was observed to have $84 \%$ activity after 5 days of incubation and was able to maintain more than $72 \%$ of its original activity after 10 days, which indicates that the immobilization of the enzymes decreases the likelihood of its denaturation (Zhang et al., 2011). Munjal and Sawhney (2002) also obtained $65-75 \%$ retention in enzyme activity with tyrosinase immobilized onto polyacrylamide gel after 14 days of incubation. Bayramoglu et al. (2013) had also observed $80 \%$ retention of activity after 14 days of incubation with tyrosinase immobilized onto biosilica. The greater stability of the immobilized enzyme may also be ascribed as an effect of film (Munjal and Sawhney, 2002), which provides a biocompatible microenvironment to the enzyme (Schnapp and Shalitin, 1976). These results are also in agreement with the previous studies done by several groups on enzyme immobilization (Edwards et al., 1999; Bayramoglu et al., 2011; Karagoz et al., 2011; Nicolucci et al., 2011). The reproducibility of the immobilized enzyme preparation is an important attribute for large-scale applications. The immobilized tyrosinase maintained $84 \%$ of its activity and produced $1.23 \mathrm{mg} \mathrm{ml}^{-1} \mathrm{~L}$-DOPA even following six successive cycles (Figure 7B). Munjal and Sawhney (2002) also obtained $75-85,60-70$, and $45-50 \%$ retention in enzyme activity after 5 cycles of reuses with tyrosinase immobilized onto alginate, polyacrylamide and gelatin gel, respectively, whereas, Labus et al. (2011) observed 45-65\% retention in Agaricus bisporus tyrosinase activity after 6 reuses when it was immobilized onto cellulose based carriers. Further $80 \%$ of the enzyme activity was retained following 7 cycles with tyrosinase immobilized onto polystyrene microplate (Saini et al., 2014). Higher retention of enzyme activity and ability to produce L-DOPA following repetitive usage may be attributed to the effective adsorption of enzyme onto the polymer matrix, thus making it promising and amenable for consistent usage for industrial exploitations.

\section{CONCLUSIONS}

In the present study, tyrosinase from a fungal source, A. niger PA2 was immobilized onto a composite of two biopolymers: chitosan and gelatin. This is the first report where tyrosinase extracted from A. niger was immobilized onto chitosan-gelatin copolymer matrix and evaluated for its activity and L-DOPA synthesis. Being biocompatible, this unique composite film provided a suitable natural microenvironment, which could successfully offer efficient loading and thus prevent the leaching of the immobilized enzyme. The enzyme adsorbed onto the co-polymer matrix exhibited notably increased thermal and $\mathrm{pH}$ stability. The immobilized preparation was stable for 20 days and could be reused for multiple cycles. The reusability of enzyme-copolymer system may provide cost-effective strategy for large-scale production of L-DOPA. Thus, the proposed blend of the enzymebiocomposite film may provide a promising and viable system for L-DOPA production and for a wide range of biotechnological applications.

\section{AUTHOR CONTRIBUTIONS}

All authors listed, have made substantial, direct and intellectual contribution to the work, and approved it for publication. 


\section{ACKNOWLEDGMENTS}

Research fellowships awarded to PA by University Grant Commission (2121030975), Govt. of India, to SD by

\section{REFERENCES}

Agarwal, P., Pareek, N., Dubey, S., Singh, J., and Singh, R. P. (2016). Aspergillus niger PA2: a novel strain for extracellular biotransformation of L-Tyrosine into L-DOPA. Amino Acids 48, 1253-1262. doi: 10.1007/s00726-016-2174-7

Arica, M. Y., and Bayramoglu, G. (2006). Invertase reversibly immobilized onto polyethylenimine-grafted poly(GMA-MMA) beads for sucrose hydrolysis. J. Mol. Catal. B Enzym. 38, 131-138. doi: 10.1016/j.molcatb.2005.12.006

Arica, M. Y., Bayramoglu, G., and Bicak, N. (2007). Characterization of tyrosinase immobilized onto spacer-arm attached glycidyl methacrylate-based reactive microbeads. Proc. Biochem. 39, 2007-2017. doi: 10.1016/j.procbio.2003.09.030

Arnow, E. L. (1937). Colorimetric determination of the components of L-3, 4-dihydroxy phenyl alanine-tyrosine mixtures. J. Biol. Chem. 118, 531-537.

Arvanitoyannis, I. S., Nakayama, A., and Aiba, S. I. (1998). Chitosan and gelatin based edible films: state diagrams, mechanical and permeation properties. Carbohydr. Polym. 37, 371-382. doi: 10.1016/S0144-8617(98)00083-6

Atlow, S. C., Banadonna-Aparo, L., and Klibanov, A. M. (1984). Dephenolization of industrial wastewaters catalyzed by polyphenol oxidase. Biotechnol. Bioeng. 26, 599-603. doi: 10.1002/bit.260260607

Basavaraju, K. C., Damappa, T., and Rai, S. K. (2006). Preparation of chitosan and its miscibility studies with gelatin using viscosity, ultrasonic and refractive index. Carbohydr. Polym. 66, 357-362. doi: 10.1016/j.carbpol.2006.03.020

Bayramoglu, G., Akbulut, A., and Arica, M. Y. (2013). Immobilization of tyrosinase on modified diatom biosilica: Enzymatic removal of phenolic compounds from aqueous solution. J. Hazard. Mater. 244-245, 528-536. doi: 10.1016/j.jhazmat.2012.10.041

Bayramoglu, G., Altıntas, B., Yilmaz, M., and Arica, M. Y. (2011). Immobilization of chloroperoxidase onto highly hydrophilic polyethylene chains via bioconjugation: catalytic properties and stabilities. Biores. Technol. 102, 475-482. doi: 10.1016/j.biortech.2010.08.056

Bayramoglu, G., and Arica, M. Y. (2010). Reversible immobilization of catalase on fibrous polymer grafted and metal chelated chitosan membrane. J. Mol. Catal. B Enz. 62, 297-304. doi: 10.1016/j.molcatb.2009.11.013

Bayramoglu, G., Gursel, I., Yilmaz, M., and Arica, M. Y. (2012). Immobilization of laccase on itaconic acid grafted and $\mathrm{Cu}(\mathrm{II})$ ion chelated chitosan membrane for bioremediation of hazardous materials. J. Chem. Technol. Biotechnol. 87, 530-539. doi: 10.1002/jctb.2743

Bullock, C. (1995). Immobilized enzymes. Sci. Progr. 78, 119-134.

Chen, T., Embree, H. D., Brown, E. M., Taylor, M. M., and Payne, G. F. (2003). Enzyme-catalyzed gel formation of gelatin and chitosan: potential for in situ applications. Biomaterials 24, 2831-2841. doi: 10.1016/S0142-9612(03) 00096-6

Chen, T., Vazquez-Duhalt, R., Wu, C. F., Bentley, W. E., and Payne, G. F. (2001). Combinatorial screening for enzyme-mediated coupling. Tyrosinase-Catalyzed coupling to create protein-chitosan conjugates. Biomacromolecules 2, 456-462. doi: $10.1021 / \mathrm{bm} 000125 \mathrm{w}$

Cirpan, A., Alkan, S., Toppare, L., Hepuzer, Y., and Yagci, Y. (2003). Immobilization of invertase in conducting copolymers of 3-methylthienyl methacrylate. Bioelectrochemistry 59, 29-33. doi: 10.1016/S1567-5394(02)00186-X

Cruz, J., Kawasaki, M., and Gorski, W. (2000). Electrode coatings based on chitosan scaffolds. Anal. Chem. 72, 680-686. doi: 10.1021/ac990954b

Edwards, W., Bownes, R., Leukes, W. D., Jacobs, E. P., Sanderson, R., Rose, P. D., et al. (1999). A capillary membrane bioreactor using immobilized polyphenol oxidase for the removal of phenols from industrial effluents. Enz. Microb. Technol. 24, 209-217. doi: 10.1016/S0141-0229(98)00110-0

Ensuncho, L., Alvarez-Cuenca, M., and Legge, R. L. (2005). Removal of aqueous phenol using immobilized enzymes in a bench scale and pilot scale three-phase fluidized bed reactor. Bioproc. Biosyst. Eng. 27, 185-191. doi: 10.1007/s00449-005-0400-x
Department of Biotechnology (DBT-JRF/10-11/318), Govt. of India and to MS by Ministry of Human Resource Development (MHR02-23-200-429), Govt. of India are gratefully acknowledged.

Fiorentino, D., Gallone, A., Fiocco, D., Palazzo, G., and Mallardi, A. (2010). Mushroom tyrosinase in polyelectrolyte multilayers as an optical biosensor for o-diphenols. Biosens. Bioelectron. 25, 2033-2037. doi: $10.1016 /$ j.bios.2010.01.033

Forzani, E. S., Rivas, G. A., and Solís, V. M. (1999). Kinetic behaviour of dopamine-polyphenol oxidase on electrodes of tetrathiafulvalenium tetracyanoquinodimethanide and tetracyanoquinodimethane species. $J$. Electroanal. Chem. 461, 174-183. doi: 10.1016/S0022-0728(98)00119-3

Forzani, E. S., Solís, V. M., and Calvo, E. J. (2000). Electrochemical behavior of polyphenol oxidase immobilized in self-assembled structures layer by layer with cationic polyallylamine. Anal. Chem. 72, 5300-5307. doi: 10.1021/ac0003798

Gupte, A., and D'Souza, S. F. (1999). Stabilization of alginate beads using radiation polymerized polyacrylamide. J. Biochem. Biophys. Met. 40, 39-44. doi: 10.1016/S0165-022X(99)00015-9

Jha, S. K., and D'Souza, S. F. (2005). Preparation of polyvinyl alcoholpolyacrylamide composite polymer membrane by $\gamma$-irradiation for entrapment of urease. J. Biochem. Biophys. Methods 62, 215-218. doi: 10.1016/j.jbbm.2004.11.006

Karagoz, B., Bayramoglu, G., Altintas, B., Bicak, N., and Arica, M. Y. (2011). Amine functional monodispersemicrobeads via precipitation polymerization of $\mathrm{N}$ vinyl formamide: immobilized laccase for benzidine based dyes degradation. Biores. Technol. 102, 6783-6790. doi: 10.1016/j.biortech.2011.03.050

Labus, K., Turek, A., Liesiene, J., and Bryjak, J. (2011). Efficient Agaricus bisporus tyrosinase immobilization on cellulose-based carriers. Biochem. Eng. J. 56, 232-240. doi: 10.1016/j.bej.2011.07.003

Li, Y. F., Liu, Z. M., Liu, Y. L., Yang, Y. H., Shen, G. L., and Yu, R. Q. (2006). Mediator-free phenol biosensor based on immobilizing tyrosinase to $\mathrm{ZnO}$ nanoparticles. Anal. Biochem. 349, 33-40. doi: 10.1016/j.ab.2005.11.017

Li, Y., Quan, J., Branford-White, C., Williams, G. R., Wu, J. X., and Zhu, L. M. (2012). Electrospun polyacrylonitrile-glycopolymer nanofibrous membranes for enzyme immobilization. J. Mol. Catal. B Enz. 76, 15-22. doi: 10.1016/j.molcatb.2011.12.003

Liu, A., Honma, I., and Zhou, H. (2005). Amperometric biosensor based on tyrosinase-conjugated polysaccharide hybrid film: selective determination of nanomolar neurotransmitters metabolite of 3,4-dihydroxyphenylacetic acid (DOPAC) in biological fluid. Biosens. Bioelectr. 21, 809-816. doi: 10.1016/j.bios.2005.03.005

Liu, N., Zhang, T., Wang, Y. J., Huang, Y. P., Ou, J. H., and Shen, P. (2004). A heat inducible tyrosinase with distinct properties from Bacillus thuringiensis. Lett. Appl. Microbiol. 39, 407-412. doi: 10.1111/j.1472-765X.2004.01599.x

Lo'pez-Caballero, M. E., Go'mez-Guille'n, M. C., Pe'rez-Mateos, M., and Montero, P. (2005). A chitosan-gelatin blend as a coating for fish patties. Food Hydrocoll. 19, 303-311. doi: 10.1016/j.foodhyd.2004.06.006

Mateo, C., Palomo, J. M., Fernandez-Lorente, G., Guisan, J. M., and FernandezLafuente, R. (2007). Improvement of enzyme activity, stability and selectivity via immobilization techniques. Enz. Microb. Technol. 40, 1451-1463. doi: 10.1016/j.enzmictec.2007.01.018

Mi, F. L. (2005). Synthesis and characterization of a novel chitosan-gelatin bioconjugate with fluorescence emission. Biomacromolecules 6, 975-987. doi: $10.1021 / \mathrm{bm} 049335 \mathrm{p}$

Monsan, P. (1978). Optimization of glutaraldehyde activation of a support for enzyme immobilization. J. Mol. Catal. 3, 371-384. doi: 10.1016/0304-5102(78)80026-1

Munjal, N., and Sawhney, S. K. (2002). Stability and properties of mushroom tyrosinase entrapped in alginate, polyacrylamide and gelatin gels. Enz. Microb. Technol. 30, 613-619. doi: 10.1016/S0141-0229(02)00019-4

Nicolucci, C., Rossi, S., Menale, C., Godjevargova, T., Ivanov, Y., Bianco, M., et al. (2011). Biodegradation of bisphenols with immobilized laccase or tyrosinase on polyacrylonitrile beads. Biodegradation 22, 673-683. doi: $10.1007 / \mathrm{s} 10532-010-9440-2$ 
Ramya, R., Sudha, P. N., and Mahalakshmi, J. (2012). Preparation and characterization of chitosan binary blend. Int. J. Sci. Res. Publ. 2.

Raval, K. M., Vaswani, P. S., and Majumder, D. R. (2012). Biotransformation of a single amino-acid L-Tyrosine into a bioactive molecule L-DOPA. Int. J. Sci. Res. Publ. 2, 1-9.

Saini, A. S., Kumar, J., and Melo, J. S. (2014). Microplate based optical biosensor for L-DOPA using tyrosinase from Amorphophallus campanulatus. Anal. Chim. Acta 849, 50-56. doi: 10.1016/j.aca.2014.08.016

Schnapp, J., and Shalitin, Y. (1976). Immobilization of enzymes by covalent binding to amine supports via cyanogen bromide activation. Biochem. Biophys. Res. Commun. 70, 8-14. doi: 10.1016/0006-291X(76)91101-3

Smitha, B., Sridhar, S., and Khan, A. A. (2005). Chitosan-sodium alginate polyion complexes as fuel cell membranes. Eur. Polym. J. 41, 1859-1866. doi: 10.1016/j.eurpolymj.2005.02.018

Tan, Y., Deng, W., Ge, B., Xie, Q., Huang, J., and Yao, S. (2009). Biofuel cell and phenolic biosensor based on acid-resistant laccase-glutaraldehyde functionalized chitosan-multiwalled carbon nanotubes nanocomposite film. Biosens. Bioelectr. 24, 2225-2231. doi: 10.1016/j.bios.2008.11.026

Tembe, W. S., Karve, M., Inamdar, S., Haram, S., Melo, J., and D’Souza, S. F. (2006). Development of electrochemical biosensor based on tyrosinase immobilized in composite biopolymeric. Anal. Biochem. 349, 72-77. doi: 10.1016/j.ab.2005.11.016

Vogel, H. J. (1956). A convenient growth medium for Neurospora (Medium N). Microb. Genet. Bull. 13, 42-43.

Wang, Z. G., Wan, L. S., Liu, Z. M., Huang, X. J., and Xu, Z. K. (2009). Enzyme immobilization on electrospun polymer nanofibers: an overview. J. Mol. Catal. B Enzym. 56, 189-195. doi: 10.1016/j.molcatb.2008.05.005
Xu, H., Dai, H., and Chen, G. (2010). Direct electrochemistry and electrocatalysis of hemoglobin protein entrapped in graphene and chitosan composite film. Talanta 81, 334-338. doi: 10.1016/j.talanta.2009.12.006

Xu, Y., Ren, X., and Hanna, M. A. (2006). Clay nanocomposite film preparation and characterization. J. Appl. Polym. Sci. 99, 1684-1691. doi: 10.1002/app.22664

Ye, P., Xu, Z. K., Che, A. F., Wu, J., and Seta, P. (2005). Chitosan-tethered poly(acrylonitrile-co-maleic acid) hollow fiber membrane for lipase immobilization. Biomaterials 26, 6394-6403. doi: 10.1016/j.biomaterials.2005.04.019

Yildiz, H. B., Caliskan, S., Kamaci, M., Caliskan, A., and Yilmaz, H. (2013). l-Dopa synthesis catalyzed by tyrosinase immobilized in poly(ethyleneoxide) conducting polymers Huseyin. Int. J. Biol. Macromol. 56, 34-40. doi: 10.1016/j.ijbiomac.2013.01.031

Zhang, Y., Li, L., Yu, C., and Hei, T. (2011). Chitosan-coated polystyrene microplate for covalent immobilization of enzyme. Anal. Bioanal. Chem. 401, 2311-2317. doi: 10.1007/s00216-011-5306-7

Conflict of Interest Statement: The authors declare that the research was conducted in the absence of any commercial or financial relationships that could be construed as a potential conflict of interest.

Copyright (c) 2016 Agarwal, Dubey, Singh and Singh. This is an open-access article distributed under the terms of the Creative Commons Attribution License (CC BY). The use, distribution or reproduction in other forums is permitted, provided the original author(s) or licensor are credited and that the original publication in this journal is cited, in accordance with accepted academic practice. No use, distribution or reproduction is permitted which does not comply with these terms. 